\title{
KREDYTOWANIE NALEŻNOŚCI CELNYCH NA GRUNCIE USTAWY Z DNIA 31 LIPCA 1924 ROKU W PRZEDMIOCIE UREGULOWANIA STOSUNKÓW CELNYCH
}

\section{WPROWADZENIE}

Polityka celna stanowiła trwały element rzeczywistości ekonomicznej każdego państwa. Należy jednak zaznaczyć, iż w niepodległej Polsce system celny kształtował się w nieustabilizowanej sytuacji politycznej, gospodarczej oraz prawnej. Chaos legislacyjny i mozaika prawna będąca konsekwencją odziedziczenia systemów prawnych państw zaborczych, a także trudna sytuacja gospodarcza wynikająca z jednej strony z konieczności odbudowy gospodarczej zrujnowanego wojną państwa, a z drugiej z inflacji waluty w związku z rosnącym kryzysem gospodarczym nie tylko w Polsce, ale i na świecie zadecydowały o tym, że taryfa celna i przepisy wykonawcze prawa celnego miały charakter efemeryczny. Brak kompleksowych uregulowań w zakresie ustawodawstwa celnego stanowił podstawę do udzielania szeregu specjalnych przywilejów poszczególnym dzielnicom, w rezultacie pogłębiając wyłom w jednolitej strukturze systemu celnego, którą rząd polski starał się uzyskać poprzez odpowiednią politykę celną ${ }^{1}$.

Pomimo bogatego ustawodawstwa międzywojennego dotyczącego cła, tematyka dotycząca kredytu celnego pojawiła się dopiero na gruncie ustawy z dnia

Dr Judyta Dworas-Kulik - asystent w Katedrze Historii Ustroju i Prawa, Instytut Nauk Prawnych, Wydział Prawa, Prawa Kanonicznego i Administracji Katolickiego Uniwersytetu Lubelskiego Jana Pawła II, Al. Racławickie 14, 20-950 Lublin; e-mail: judytadworas@kul.pl; https://orcid. org/0000-0002-1990-5497

${ }^{1}$ G. Mosies, Dzieje polityki celnej Polski w zarysie, „Ekonomia. Rynek, Gospodarka, Społeczeństwo" 4 (2001), s. 206; W. KRZYwICKI, Dzieje polityki celnej. Zarys historyczny ustawodawstwa celnego ze specjalnym uwzględnieniem cet zbożowych, Warszawa: ZPOR 1925, s. 151-180; P.M. PilarczyK, Polityka gospodarcza jako czynnik ksztaltowania rozwiązan prawnych. Wptyw na regulacje celne w polskiej skarbowości od XVIII do XX wieku, „Studia z Dziejów Państwa i Prawa” 16 (2013), s. 81-84. 
31 lipca 1924 r. w przedmiocie uregulowania stosunków celnych ${ }^{2}$. Przepis art. 7 lit. c wolą ustawodawcy zezwalał Ministrowi Skarbu w porozumieniem z Ministrem Przemysłu i Handlu oraz z Ministrem Rolnictwa i Dóbr Państwowych, do czasu ustalenia się stosunków gospodarczych, uzupełnić drogą rozporządzeń tymczasowych obowiązujące przepisy celne postanowieniami o kredytowaniu należności celnych, a także odraczaniu terminów wpłat tych należności. Niniejsza ustawa została uchylona rozporządzeniem Prezydenta Rzeczypospolitej Polskiej z dnia 27 października 1933 r. o prawie celnym ${ }^{3}$ obowiązującym aż do 1961 r., kiedy to uchwalono ustawę Prawo celne ${ }^{4}$.

\section{WARUNKI UDZIELENIA KREDYTU CELNEGO}

W transporcie lądowym zgodnie z rozporządzeniem Ministrów: Skarbu, Przemysłu i Handlu oraz Rolnictwa i Dóbr Państwowych z dnia 26 lutego 1925 r. w sprawie kredytowania należności celnych ${ }^{5}$ przy przewozie towarów z zagranicy mogły być przyznawane importerom kredyty na należności celne do wysokości pewnej ściśle określonej kwoty. Przyznanie kredytu celnego miało charakter uznaniowy, zależny od Ministerstwa Skarbu, w związku z czym kredytowanie mogło wcale nie zostać udzielone bądź w każdej chwili przerwane bez podania przyczyn tychże decyzji $(\S 1, \S 5)$. Ogólną sumę udzielanych kredytów celnych oznaczało co pół roku Ministerstwo Skarbu (§ 2). W drodze zarządzenia określało ono również minimalną sumę kredytu celnego przyznawanego importerom, a ponadto ustalało stopę procentową dla danego kredytu celnego $(\S 3 \text { i } \S 9)^{6}$. Przepis $\S 4$ rozporządzenia wskazywał, iż z omawianej instytucji mogły korzystać zakłady wytwórcze, zakłady użyteczności publicznej, instytucje samorządowe, zrzeszenia producentów rolnych i hurtowe domy składowe, o ile zasługiwały na zaufanie, przedstawiały rękojmię wypłacalności, tj. złożyły wystarczające zabezpieczenie w postaci państwowych papierów procentowych, bankowych listów gwarancyjnych i zabezpieczenia hipotecznego ( $(7)$, oraz prowadziły księgi handlowe zgodnie

${ }^{2}$ Dz. U. Nr 80, poz. 777.

${ }^{3}$ Dz. U. Nr 84, poz. 610.

${ }^{4}$ Ustawa z 14 lipca 1961 r. - Prawo celne, Dz. U. Nr 33, poz. 166.

${ }^{5}$ Dz. U. Nr 26 poz. 186. Przez kredyt celny rozumiano odroczenie zapłaty cła, którego płatność już zapadła. Władze celne prowadziły wykaz należności celnych, tj. zaległych sum. Importer jako płatnik celny uznawał swoje zobowiązanie w specjalnym dokumencie, którego zwrot otrzymywał dopiero po uiszczeniu cła.

${ }^{6}$ Suma kredytu celnego wynosiła $2 \%$ więcej niż stopa procentowa pobierana przez Bank Polski od pożyczek terminowych. 
z obowiązującymi przepisami. Kredytowaniu podlegało cło od wszelkich towarów, które służyły do celów przemysłowych lub do zwiększenia i zminimalizowania kosztów produkcji surowców, półfabrykatów, środków produkcji, artykułów pierwszej pomocy ( $(6)$. Kredytowane należności celne co do zasady należało spłacić w terminie dwumiesięcznym od dnia określenia wymiaru zobowiązania celnego. Jednak Ministerstwo Skarbu mogło wskazany termin wydłużyć do 4 miesięcy ( 8). Brak terminowej spłaty kredytu celnego wiązał się ze ściąganiem należności na drodze przymusu egzekucyjnego (§ 10).

$\mathrm{W}$ transporcie morskim prawne regulacje dotyczące kredytu celnego zostały zawarte w rozporządzeniu Ministrów: Skarbu, Przemysłu i Handlu oraz Rolnictwa z dnia 30 kwietnia 1930 r. w sprawie kredytowania należności celnych od towarów sprowadzanych drogą morską przez Gdynię ${ }^{7}$. Na mocy § 1 niniejszego rozporządzenia przy przewozie towarów z zagranicy na statkach morskich mogły być przyznawane importerom (armatorom) oprocentowane kredyty na należności celne pod warunkiem złożenia wystarczającego zabezpieczenia (zob. § $4, \S 6)^{8}$. Terminy na uiszczenie zobowiązania pod groźbą ściągnięcia należności w drodze przymusowej ustalono analogicznie, jak w rozporządzeniu z 26 lutego 1925 r., a zatem dwumiesięczny termin na spłatę kredytu mógł zostać wydłużony wolą Ministerstwa Skarbu do 4 miesięcy ( $(5)$. Katalog podmiotów uprawnionych do korzystania $\mathrm{z}$ kredytu celnego w ustawodawstwie morskim został rozszerzony o firmy handlowe, przemysłowe i ekspedycyjne ${ }^{9}$, które przedstawiały rękojmię wypłacalności i jednocześnie prowadziły księgi handlowe zgodnie z obowiązującymi przepisami (§ 2). Odmienny w omawianym rozporządzeniu był również

${ }^{7}$ Dz. U. Nr 46, poz. 388. Podstawę prawną niniejszego rozporządzenia stanowiła ustawa z dnia 31 lipca 1924 r. w przedmiocie uregulowania stosunków celnych, Dz. U. 1924 nr 80 poz. 777.

${ }^{8}$ Rozporządzenie analogicznie jako zabezpieczenie wskazuje papiery procentowe, bankowe listy gwarancyjne i zabezpieczenia hipoteczne. Warto zaznaczyć, iż uregulowania prawne dotyczące umownego zastawu na statku morskim, pomimo, iż jest on rzeczą ruchomą zbliżone są do przepisów odnoszących się do hipoteki na nieruchomości, stąd też w obrocie prawnym stosuje się nazwę hipoteka morska. Bliżej na ten temat: J. Dworas-Kulik, Hipoteka morska w Polsce w okresie międzywojennym, [w]: Badania i Rozwój Młodych Naukowców w Polsce. Nauki humanistyczne i społeczne, cz. 1, red. J. Nyćkowiak, J. Leśny, Poznań: MN 2018, s. 122-127; TAż, Rzeczowe zabezpieczenie wierzytelności morskich w międzywojennej Polsce, „Roczniki Nauk Prawnych” 28 (2018), nr 3, s. 42-45. Por. W. SowiŃski, Hipoteka morska z punktu widzenia kodyfikacyjnego, „Gazeta Sądowa Warszawska” 65 (1938), nr 5, s. 67-69; M.H. KozIŃSKI, Ewolucja przepisów o hipotece morskiej w prawie polskim, ,Rejent” 107 (2000), nr 3, s. 30-57.

${ }^{9}$ Zob. Rozporządzenie Ministra Skarbu z dnia 6 października 1920 r. w przedmiocie dopuszczenia przedsiębiorstw ekspedycyjnych do pośrednictwa w załatwianiu formalności celnych, Dz. U. Nr 103, poz. 686 . 
wykaz towarów, od których cło podlegało zakredytowaniu, bowiem załącznik do rozporządzenia Rady Ministrów z dnia 10 lutego 1928 r. zawierał spis wyłączeńn ${ }^{10}$.

\section{DOKUMENTY NIEZBĘDNE DO UDZIELANIA KREDYTU CELNEGO}

Aktem wykonawczym dla rozporządzenia z dnia 26 lutego 1925 r. oraz dla rozporządzenia z dnia 30 kwietnia 1930 r. było rozporządzenie Ministra Skarbu z dnia 30 marca 1925 r. w sprawie postępowania przy udzielaniu kredytów celnych $^{11}$. Zgodnie z $\S 1$ tegoż rozporządzenia przy opłacie ceł przewozowych i innych należności celnych, pobieranych przez urzędy celne, w tym także morski urząd celny, udzielony kredyt każdorazowo musiał być ściśle określony. Do udzielania kredytów upoważnione zostały dyrekcje ceł, które w razie wątpliwości przy podejmowaniu decyzji kredytowej zwracały się do Ministerstwa Skarbu z prośbą o ostateczne rozstrzygnięcie sprawy ( $(2)$. Ministerstwo Skarbu po ustaleniu budżetu określało ryczałtową sumę kredytów celnych i rozdzielało ją zgodnie ze wspomnianym wyżej rozporządzeniem co pół roku pomiędzy poszczególne dyrekcje ceł z prawem przyznawania im kredytów celnych w granicach wyznaczonych sum (§3). Jednym z warunków udzielenia kredytu była należność z tytułu cła nie mniejsza niż $5000 \mathrm{zł} \mathrm{(§} \mathrm{4).} \mathrm{Ponadto} \mathrm{importer} \mathrm{ubiegając} \mathrm{się} \mathrm{o} \mathrm{kredyt} \mathrm{miał}$ w podaniu złożonym do właściwej dyrekcji ceł podać wysokość kredytu, o który się ubiegał i formę jego zabezpieczenia, a także wskazać towary sprowadzone do kraju oraz urząd celny właściwy do oclenia tychże towarów (§ 5). Co istotne, w przypadku zabezpieczenia powstałej wierzytelności gwarancją bankową, do wniosku wymagano załączenia zaświadczenia $\mathrm{z}$ banku z promesą potwierdzającą wystawienie gwarancji (stosowano wzór zaświadczenia obowiązujący kredytobiorcę, § 14). Natomiast w przypadku zabezpieczenia w państwowych papierach procentowych konieczne było wyszczególnienie planowanych do złożenia papierów (wartość kursów tychże papierów ustalało Ministerstwo Skarbu, § 7), zaś w sytuacji zadeklarowania złożenia zabezpieczenia hipotecznego należało do wniosku

\footnotetext{
${ }^{10}$ Rozporządzenie Rady Ministrów z dnia 10 lutego 1928 r. w sprawie uchylenia zakazu przywozu niektórych towarów, Dz. U. Nr 15 poz. 113. Załącznik do rozporządzenia wymienia m.in. produkty spożywcze, np.: świeże ziemniaki, kapustę, owoce: świeże, w alkoholu, w cukrze i suszone oprócz przewożonych luzem bądź w beczkach i workach bez wewnętrznego opakowania, chleb świętojański, orzechy, przyprawy i pasztety, cukierki, konfitury, serki, owocowe galaretki, proszki i pastylki do wyrobu napojów i alkoholi, wybrane alkohole, sery, ryby itd. Załącznik obejmuje również wykaz towarów codziennego użytku, jak np.: kapelusze, czapki, parasole, kosmetyki, perfumy, wyroby ze srebra, złota, platyny i porcelanowe, szyby lustrzane i lustra, samochody osobowe, motocykle, instrumenty i urządzenia muzyczne oraz różnego rodzaju tkaniny.
}

${ }^{11}$ Dz. U. Nr 40, poz. 277. 
kredytowego załączyć wyciąg z księgi gruntowej właściwej dla danej nieruchomości wraz z protokołem oszacowania sądowego tej nieruchomości. W przypadku zabudowania nieruchomości budynkami dodatkowo wymagano przedstawienia dokumentu potwierdzającego ich ubezpieczenie od ognia do kwoty pokrywającej wartość zastawu skarbowego oraz corocznego przedstawiania dowodów opłat z tytułu rat asekuracyjnych ( $(18)$. Przy położeniu nieruchomości na obszarze byłego zaboru rosyjskiego wymagano ekspertyzy zlecanej przez dyrekcje ceł, której koszty pokrywał wnioskodawca kredytu ${ }^{12}$ oraz zapisania ewikcji hipotecznej na zabezpieczeniu kredytu celnego w formie aktu notarialnego (§ 15). Z kolei przy zabezpieczeniach hipotecznych poza terenem byłego zaboru rosyjskiego petent miał wystawić dokument zastawu w przepisanej formie, a następnie na własny koszt uskutecznić wpis zastawu hipotecznego na rzecz Skarbu Państwa. Do dyrekcji ceł należało bowiem złożyć uchwałę hipoteczną wraz z wyciągiem z księgi gruntowej wskazującym wpis ewikcji (§16).

Akceptowalną wartość zabezpieczenia hipotecznego zatwierdzała Prokuratoria Generalna Rzeczypospolitej Polskiej (§ 6, § 8, 9 ). Zabezpieczenie hipoteczne mogło być udzielone przez osobę trzecią, która w dokumencie zastawu lub w zapisie ewikcji hipotecznej zobowiązywała się do solidarnej odpowiedzialności za terminową spłatę zobowiązania (§ 17). Maksymalna wysokość kredytu udzielanego przy zabezpieczeniu hipotecznym nie mogła przekroczyć 75\% wartości obrotowej nieruchomości, po potrąceniu wartości obciążeń hipotecznych poprzedzających wpis zabezpieczający i przynajmniej $25 \%$ wartości kredytu przeznaczanego na odsetki i koszty egzekucji ( $§ 10)$. Zabezpieczenie spłaty kredytu należało złożyć na czas trwania kredytu jako depozyt. Zwrot lub cofnięcie zabezpieczenia następowało dopiero po wygaśnięciu wszelkich zobowiązań (§ 11, § 20). Warto dodać, iż każdorazowe korzystanie z przyznanego kredytu celnego wymagało adnotacji na deklaracji celnej bądź pisemnego zgłoszenia dołączanego do właściwej deklaracji (§ 24). Następnie urzędnik sprawdzał czy importer dysponuje środkami przyznanymi w ramach kredytu oraz sprawdzał czy zadeklarowany do oclenia towar odpowiada towarom wskazanym w pozwoleniu (§ 25$)$.

\footnotetext{
12 Przed zleceniem ekspertyzy wpłacano zaliczkę na poczet kosztów oszacowania wartości nieruchomości.
} 


\section{ZADANIA DYREKCJI CEŁ I URZĘDÓW CELNYCH W ZWIĄZKU Z UDZIELENIEM KREDYTU CELNEGO}

Zawiadomienie od dyrekcji ceł o przyznaniu kredytu przesyłano w dwóch egzemplarzach. Wskazywano w nich sumę wraz z procentami, termin spłaty przyznanego kredytu oraz żądanie złożenia odpowiedniego zabezpieczenia $(\S 12, \S 27$ rozporządzenia z dnia 30 kwietnia 1930 r.). Ubiegający się o kredyt na jednym z przesłanych egzemplarzy deklarował ścisłe przestrzeganie wskazanych warunków, zaś jego podpis poświadczał notariusz (§ 13). Po otrzymaniu zobowiązania strony oraz stosownego zabezpieczenia, dyrekcja ceł zawiadamiała właściwy urząd celny podając mu jednocześnie wszystkie dane niezbędne do wykonywania czynności wynikających z danego zobowiązania kredytowego. Odpis zarządzenia dyrekcja ceł przesyłała do wiadomości petenta (§ 19). Dyrekcja ceł w jednym pozwoleniu mogła udzielić importerowi kredytu celnego w kilku urzędach celnych. Ogólna suma kredytu rozdzielała się wtedy pomiędzy poszczególne urzędy, które w granicach przydzielonych sum prowadziły w specjalnych księgach ewidencję i odpowiadały za ściągnięcie wierzytelności (§ 22, § 23).

Zgodnie z $§ 37$ niniejszego rozporządzenia urząd celny po miesięcznym zamknięciu księgi zakredytowanych należności przesyłał w terminie 5 dni do dyrekcji ceł „wykaz zakredytowanych należności” podając jednocześnie na odwrotnej stronie sumę niewpłaconych w danym miesiącu sprawozdawczym ceł oraz oddzielnie poszczególnych wpływów ubocznych wynikających z oprocentowania kredytu. Dyrekcja ceł była zobowiązana do ścisłej kontroli czynności urzędów celnych, a także do szybkiego i dokładnego sprawdzania nadsyłanych sprawozdań i dokumentów w sprawach kredytowania cła $(\S 40)$. Na podstawie otrzymanych wykazów w terminie 10 dni dyrekcja ceł sporządzała i przesyłała departamentowi ceł oraz właściwym izbom kontroli „ogólny wykaz zakredytowanych należności”, a także otrzymane od urzędów celnych tymczasowe i ostateczne wykazy z zapisaną na odwrotnej stronie ogólną sumą zakredytowanych w miesiącu sprawozdawczym ceł oraz wpływów ubocznych (§38). Ponadto dyrekcje ceł były zobligowane co dziesięć dni przesyłać do departamentu ceł krótkie sprawozdania wskazujące komu, ile oraz na jaki termin został przyznany kredyt z sumy przyznawanej do dyspozycji dyrekcji ceł (§ 39). Departament ceł ostatniego dnia każdego miesiąca przesyłał do Najwyższej Izby Kontroli ogólny wykaz zakredytowanych należności celnych za miesiąc poprzedni podając nazwę dyrekcji ceł oraz sumy ogólne z wykazów poszczególnych dyrekcji (§ 41). 


\section{SPŁATA KREDYTOWANYCH NALEŻNOŚCI CELNYCH}

Wysokość oprocentowania zakredytowanych należności naliczano w momencie dokonywania wpłaty, którą kwitowano w sposób ustalony w instrukcji rachunkowo-kasowej urzędu celnego. Dokonaną wpłatę księgowano w rejestrze opłat celnych oraz w księgach ewidencyjnych, przy czym pobrane procenty zapisywano w oddzielnej rubryce jako „wpływy uboczne” $(\S 29, \S 30$ rozporządzenia z dnia 30 kwietnia 1930 r.). Jeśli nie został przekroczony termin spłaty zobowiązania, a w związku z tym nie było konieczności naliczania karnych odsetek zgodnie $\mathrm{z} \S 26$ tegoż rozporządzenia oprocentowanie kredytu celnego wynosiło o $2 \%$ więcej niż aktualnie obowiązująca stopa procentowa pobierana przez Bank Polski od pożyczek terminowych. Wysokość stopy procentowej regulował Minister Skarbu na drodze oddzielnych zarządzeń ${ }^{13}$. Należy jednak zaznaczyć, iż przepisy $§ 26$ nie miały analogicznego zastosowania przy kredytowaniu należności celnych od towarów sprowadzanych drogą morską przez Gdynię ${ }^{14}$. Zakredytowane należności celne od towarów sprowadzanych transportem morskim podlegały oprocentowaniu między $4 \%$ a $5 \%$ w stosunku rocznym ${ }^{15}$.

Dopuszczano przedterminową spłatę każdej zadeklarowanej sumy (§ 27). Wpłat należało dokonać w kasach urzędu celnego, kasach skarbowych lub oddziałach Banku Polskiego. W przypadku dokonania wpłaty w innym miejscu niż urząd celny konieczne było powiadomienie urzędu celnego o tym fakcie i przedstawienie oryginału pokwitowania wpłaty lub uwierzytelnionego przez siebie odpisu w terminie 5 dni pod rygorem przymusowego ścigania zaległej wierzytelności ( $§ 27$, $\S 31, \S 32)^{16}$. Brak terminowej spłaty należności wiązał się z naliczeniem karnych odsetek w wysokości 50\% stopy procentowej pobieranej przez Bank Polski od pożyczek terminowych oraz ze sporządzeniem nakazu płatniczego, który przesyłano

${ }^{13} \mathrm{~W} 1925$ r. stopa procentowa kredytu celnego wynosiła 14\% w stosunku rocznym.

${ }^{14}$ Zob. $\S 8$ rozporządzenia z dnia 30 kwietnia 1930 r. Podobnie nie miał zastosowania $\S 21$ rozporządzenia z 30 marca 1925 r., gdyż odprawa celna dla transportu morskiego odbywała się w Morskim Urzędzie Celnym w Gdyni. Więcej na ten temat: B. PoźniaK, Morski Urząd Celny w przedwojennej Gdyni, „Zeszyty Gdyńskie” 7 (2012), s. 107-115.

${ }^{15}$ Rozporządzenie Ministra Skarbu z dnia 25 września 1930 r. w sprawie ustalania stopy procentowej, pobieranej przy kredytowaniu należności celnych od towarów, sprowadzanych drogą morską przez Gdynię, M. P. Nr 232, poz. 317. Por. Rozporządzenie Ministra Skarbu z dnia 17 lipca 1930 w sprawie ustalenia stopy procentowej, pobieranej przy kredytowaniu należności celnych od towarów sprowadzanych drogą morską przez Gdynię, M. P. Nr 172, poz. 260. Por. Rozporządzenie Ministra Skarbu z dnia 21 listopada $1930 \mathrm{w}$ sprawie ustalenia stopy procentowej, pobieranej przy kredytowaniu należności celnych od towarów sprowadzanych drogą morską przez Gdynię, M. P. Nr 277, poz. 378.

${ }^{16}$ Terminy wpłat przypadające w niedziele i święta przesuwały się na kolejny dzień roboczy ( 32 rozporządzenia z dnia 30 kwietnia $1930 \mathrm{r}$.). 
do odpowiedniej izby skarbowej albo policji (§ 28, § 33). Po upływie miesiąca od wysłania nakazu płatniczego dyrekcja ceł zwracała się do izby skarbowej lub policji o przyspieszenie egzekucji. Mogła również zamknąć dalsze niewyczerpane kredyty celne (§ 34, § 35), a w ostateczności zdeponować listy gwarancyjne, papiery procentowe, dokumenty hipoteczne uwzględniając w swoich roszczeniach również procenty, kary i koszty ( $\$ 36$ ). Zdeponowane zabezpieczenia przesyłała do Generalnej Prokuratorii Rzeczypospolitej Polskiej lub ewentualnie jej właściwego terytorialnie oddziału celem wszczęcia kroków prawnych zmierzających do zaspokojenia roszczeń Skarbu Państwa z tytułu kredytowanych należności celnych.

\section{PODSUMOWANIE}

Zapłata należności celnych wynikała z określenia kwoty tychże należności oraz powiadomienia importera o długu celnym. Wysokość zobowiązania na podstawie zgłoszenia celnego regulował urząd celny właściwy dla miejsca powstania niniejszego długu, a zatem zgodnie z $§ 21$ rozporządzenia z dnia 30 marca $1925 \mathrm{r}$. w sprawie postępowania przy udzielaniu kredytów celnych odprawa celna z zakredytowaniem należności celnych mogła odbywać się w Warszawie, Łodzi, Sosnowcu, Grajewie, Poznaniu, Lesznie, Zbąszyniu, Bydgoszczy, Lwowie, Przemyślu, Krakowie, Lublińcu, Katowicach, Dziedzicach, Cieszynie, Bielsku i Wilnie, zaś dla transportu drogą morską w Gdyni.

Kredyt celny miał na celu odroczenie zapłaty wymaganego cła. Odroczenie płatności niewątpliwie było ułatwieniem dla importerów, które miało pobudzić rozwój gospodarczy Rzeczypospolitej. Instytucja kredytowania należności celnych została uregulowana również na gruncie rozporządzenia Prezydenta Rzeczypospolitej Polskiej z dnia 27 października 1933 r. o prawie celnym. Ogólne założenia kredytu celnego nie uległy zmianom, bowiem art. 120 wskazywał, iż przyznanie omawianego kredytu mogło nastąpić pod warunkiem zabezpieczenia należności celnych. Minister Skarbu w dalszym ciągu ustalał warunki przyznawania kredytu celnego, sposób jego zabezpieczenia, wysokość odsetek i tok postępowania.

\section{BIBLIOGRAFIA}

\section{ŹRÓDEA PRAWA}

Ustawa z dnia 31 lipca 1924 r. w przedmiocie uregulowania stosunków celnych, Dz. U. Nr 80, poz. 777. Ustawa z 14 lipca 1961 r. - Prawo celne, Dz. U. Nr 33, poz. 166. 
Rozporządzenie Ministra Skarbu z dnia 6 października 1920 r. w przedmiocie dopuszczenia przedsiębiorstw ekspedycyjnych do pośrednictwa w załatwianiu formalności celnych, Dz. U. Nr 103, poz. 686 .

Rozporządzenie Ministrów: Skarbu, Przemysłu i Handlu oraz Rolnictwa i Dóbr Państwowych z dnia 26 lutego 1925 r. w sprawie kredytowania należności celnych, Dz. U. Nr 26, poz. 186.

Rozporządzenie Ministra Skarbu z dnia 30 marca 1925 r. w sprawie postępowania przy udzielaniu kredytów celnych, Dz. U. Nr 40, poz. 277.

Rozporządzenie Rady Ministrów z dnia 10 lutego 1928 r. w sprawie uchylenia zakazu przywozu niektórych towarów, Dz. U. Nr 15, poz. 113.

Rozporządzenie Ministrów: Skarbu, Przemysłu i Handlu oraz Rolnictwa z dnia 30 kwietnia 1930 r. w sprawie kredytowania należności celnych od towarów sprowadzanych drogą morską przez Gdynię, Dz. U. Nr 46, poz. 388.

Rozporządzenie Ministra Skarbu z dnia 17 lipca 1930 w sprawie ustalenia stopy procentowej, pobieranej przy kredytowaniu należności celnych od towarów sprowadzanych drogą morską przez Gdynię, M. P. Nr 172, poz. 260.

Rozporządzenie Ministra Skarbu z dnia 25 września 1930 r. w sprawie ustalania stopy procentowej, pobieranej przy kredytowaniu należności celnych od towarów, sprowadzanych drogą morską przez Gdynię, M. P. Nr 232, poz. 317.

Rozporządzenie Ministra Skarbu z dnia 21 listopada 1930 w sprawie ustalenia stopy procentowej, pobieranej przy kredytowaniu należności celnych od towarów sprowadzanych drogą morską przez Gdynię, M. P. Nr 277, poz. 378.

Rozporządzenie Prezydenta Rzeczypospolitej Polskiej z dnia 27 października 1933 r. o prawie celnym, Dz. U. Nr 84, poz. 610.

\section{LITERATURA}

Dworas-Kulık Judyta: Hipoteka morska w Polsce w okresie międzywojennym, [w]: Badania i Rozwój Młodych Naukowców w Polsce. Nauki humanistyczne i społeczne, cz. 1, red. J. Nyćkowiak, J. Leśny, Poznań: MN 2018, s. 122-127.

Dworas-KulIK Judyta: Rzeczowe zabezpieczenie wierzytelności morskich w międzywojennej Polsce, Roczniki Nauk Prawnych 28 (2018), nr 3, s. 35-48.

KozIŃsKi Mirosław H.: Ewolucja przepisów o hipotece morskiej w prawie polskim, Rejent 107 (2000), nr 3, s. 30-57.

KRZYwiCKi Wieńczysław: Dzieje polityki celnej. Zarys historyczny ustawodawstwa celnego ze specjalnym uwzględnieniem ceł zbożowych, Warszawa: ZPOR 1925.

MosiEj Gerard: Dzieje polityki celnej Polski w zarysie, Ekonomia. Rynek, Gospodarka, Społeczeństwo 4 (2001), s. 201-209.

Pilarczyk Piotr M.: Polityka gospodarcza jako czynnik kształtowania rozwiązań prawnych. Wpływ na regulacje celne w polskiej skarbowości od XVIII do XX wieku, Studia z Dziejów Państwa i Prawa 16 (2013), s. 73-87.

PoźNIAK Bronisław: Morski Urząd Celny w przedwojennej Gdyni, Zeszyty Gdyńskie 7 (2012), s. $107-115$.

SowiŃSKI Władysław: Hipoteka morska z punktu widzenia kodyfikacyjnego, Gazeta Sąowa Warszawska 65 (1938), nr 5, s. 67-69. 


\section{KREDYTOWANIE NALEŻNOŚCI CELNYCH NA GRUNCIE USTAWY \\ Z DNIA 31 LIPCA 1924 ROKU W PRZEDMIOCIE UREGULOWANIA STOSUNKÓW CELNYCH}

Streszczenie

Niniejsza publikacja ma na celu kompleksowe omówienie przepisów odnoszących się do zagadnienia kredytu celnego w okresie II Rzeczypospolitej. W dotychczasowej literaturze przedmiotu brak publikacji analizujących przepisy dotyczące tej instytucji, dlatego też artykuł opary został przede wszystkim na analizie ustawodawstwa międzywojennego związanego w przedmiotowym zagadnieniem. Warto zaznaczyć, iż kredyt celny w dwudziestoleciu międzywojennym był stosowany zarówno w transporcie lądowym, jak i morskim. W prowadzonych badaniach zastosowana została metoda historyczno-prawna, dogmatyczno-prawna oraz pomocniczo metoda komparatystyczna.

Słowa kluczowe: kredyt celny; cło; oclenie towarów; urząd celny; importer; transport morski

\section{CREDING OF CUSTOMS DUTIES UNDER THE LAW OF 31 JULY 1924 ON THE SETTLEMENT OF CUSTOMS RELATIONS}

\section{Sum mary}

This publication aims at a comprehensive discussion of the provisions relating to the issue of customs credit during the Second Polish Republic. In the current literature, there is no publication examining the provisions concerning this institution, and therefore the article of the fumes was first and foremost an analysis of the interwar legislation related to the issue. It is worth noting that the customs credit in the interwar period was used for both land and sea transport. The study will apply the historical-legal, dogmatic-legal and comparative method.

Key words: customs credit; duty; customs clearance of goods; the customs office; importer; ocean traffic 